\title{
I Never Thought I Would End Up In Prison: White Collar Dilemmas
}

\author{
Stephen B. Castleberry, Ph.D., University of Minnesota Duluth, USA
}

\begin{abstract}
This case allows students to hear the stories of convicted white collar prisoners from Germany and the United States and learn lessons from their mistakes. Prisoners provide details of their crimes, the resulting prison time, as well as life lessons they feel business ethics students should learn. Students are encouraged to identify anything they, themselves, might be doing that would put them on the path of illegal behavior and to consider mechanisms they can implement to avoid breaking laws. The case can be used in many courses, including Business Ethics, Managerial Accounting, Organizational Behavior, and Corporate Finance.
\end{abstract}

Keywords: White Collar Prisoner; Business Ethics; Ethics Stories

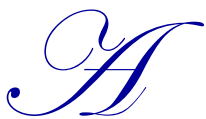

11 of the following stories are true. These people have much in common with you: they want to live a happy life provided with comforts. They did not set out in life with a goal to become convicted felons or to spend time in prison. As you read their stories, reflect upon what you learn that might help impact your life in a positive manner.

As per the agreement with each prisoner, names and details of the crime/industry have been added/changed in order to protect the actual identity of the prisoner. Each interview was conducted in accordance with protocols provided by the various countries and prison advocates and with the permission of the prisoners.

\section{CALEB}

I grew up in a small U.S. town with God-fearing parents and was an excellent student and athlete. After attending college, I spent six years teaching in public schools. I had a wife and two children and was always hungry for travel, good clothes, fine cars, and comfort, and realized I wasn't going to get it in my job as a teacher.

So I went to law school when I was 31 , took my bar exam, and ended up in my hometown where my family still lived. It was hard to make the money I wanted in a small town, so after about ten years, I started to give myself interest-free loans from my trust account. These were monies that belonged to other people that I was holding, and I had no right to do that. It was a breach of ethics and was also very illegal.

In a little while, I was taking more money than I could ever pay back, and I was in over my head. I didn't report my embezzled funds on my tax returns, and when I fraudulently filled out a tax return and mailed it in the U.S. Postal System, I was guilty of not only income tax evasion but also of mail fraud.

It started with greed and the desire to live beyond my means and ended with my being a thief and a fraud. I embarrassed my children, betrayed my wife, shamed my siblings, and besmirched my father's good name. I was deeply ashamed, and when the facts came out, and they were published in the local paper, I tried to commit suicide. I took every pill in my medicine chest, plus all the pills that belonged to my wife and my mother. I woke up three days later in the psychiatric ward of a local hospital, expecting my indictment, which came soon thereafter. I was over 60 years old yet was sentenced to 41 months in prison and instructed to pay over $\$ 600,000$ in restitution.

My wife divorced me. I have been trying to mend fences with my children and siblings, but I can never go back to the town where I was raised and where my parents are buried. 
The key lessons I have learned from this experience are two-fold in addition to the obvious lesson of keeping your hands off other people's money. First, realize that when you don't get caught, the crime gets easier, and the consequences get smaller in your mind. Don't fall into that trap! Second, I originally "borrowed" from my trust account to keep my business afloat when I was incapacitated for three months due to a heart attack. I learned that no matter what the reason - family, employees, health, whatever - it is not worth the time in jail or the ultimate humiliation of being pointed out as a thief and a fraud to all.

\section{MARK}

I was an accounting manager at a very large U.S. construction company in my mid-twenties with no prior convictions and no illegal behavior other than a few speeding tickets. I figured out how to write company checks to myself and embezzled $\$ 8.5$ million over four years. I pleaded guilty to one count of mail fraud. I was sentenced to 97 months in federal prison, thanks to amassing 30 points under the U.S. Federal Sentencing Guidelines.

It all started small. I figured out how to create a fictitious company in our company's vendor database with a name similar to one of our vendors. Since it was similar, I figured it wouldn't really get noticed much, if at all.

The first check I cut to myself was for only $\$ 1,100$. I used it to pay off part of my student loan. When I didn't get caught, I stole again, and again, each time emboldened by my success to steal larger amounts. On one day, for example, I wrote a check to my fictitious company for $\$ 400,000$. I paid off all of my credit cards, bought some fancy stuff, and lived the so-called good life. But I was not happy. I treated people badly and was into serious substance abuse.

I was amazed that the auditors never caught me stealing! It was only when a co-worker noticed my lifestyle and spending habits were way out of line given my income, that she decided to do her own investigation. When she discovered my crime, she reported it immediately.

The result of my embezzling was 5.5 years in prison, away from my family. I was left with nothing but a huge debt. You may not realize it, but when you steal you have to reimburse people for their losses, which means I have to pay back in restitution the $\$ 9$ million I stole. My family and friends have had to support me while I was away at prison in addition to supporting my children.

I used my time in prison to work on myself. I finally admitted what was wrong and worked to fix it. I was able to work on my mind, body, and soul in order to leave prison the man I always wanted to be.

College students, be aware of the choices you will be forced to make in your professional careers and how those choices can affect your life and the lives of the people you love. People assume they will make the right decision when it matters, but it doesn't always work like that. Good people make bad choices. Make sure you make the right choices when it counts. As a college graduate, I wish I had given some thought to that during my undergraduate time.

It's just a matter of time before you will be faced with an ethical and legal dilemma. It's not if you will, but when you will be faced with it.

After prison it is my goal to help people learn from my experiences through speaking and consulting. I hope to help young people avoid making the decisions I did. I also hope to help corporations learn how to spot those who are engaging in embezzlement of funds.

\section{GUNTHER}

I was a 43- year-old managing director of a successful company I owned in Germany that rented and sold industrial equipment. I had been convicted of small offences before but never anything really big. 
Now I am serving five years for embezzling money from my company. Prison time has taught me a very important lesson: freedom is the most important thing in life. If you lose your freedom, by going to prison like me, you will realize how precious it is.

While my family has generally supported me during this ordeal, and I have deepened some friendships, I've also lost some very good friends. This experience has taught me that even without much money one can be happy. Unfortunately, I learned that lesson a little too late.

I would encourage college students to think long and hard before deciding to become self-employed. Why? You become responsible for everything and pretty quickly you can get into big trouble.

When I am released at age fifty I have no intention of being self-employed or taking any type of managing director position again. I hope I can be happy with the things I have and not want more and more.

\section{GENE}

I was in my early 50s and the CEO of a very large and successful U.S. corporation that I owned. With my college education and hard work, I had created an enterprise that others sought to emulate. I had no prior convictions.

In order to expand my operations, I sought and was granted a bank loan. The loan application obviously required me to indicate exactly how I would spend the money, which I outlined completely. After receiving the funds, I changed my mind about how I would use the money. I informed the bank president of the change, and he verbally approved my change. I assumed all was in order, spent the funds and repaid the loan in full.

A while later a disgruntled bank employee became a whistle-blower and informed the bank's regulators that my loan funds had been used for a different purpose than was originally approved by the bank. Apparently the bank president had not informed the bank of my conversation with him. The regulators got involved, and the bank president decided to cooperate with the authorities in order to avoid jail time himself.

This led to a four-year investigation and trial. I was convicted of misapplication of bank funds and mail fraud and was sentenced to 71 months in prison, thanks to having amassed 25 points under the U.S. Federal Sentencing Guidelines.

I have been very fortunate that my family and my business partners all stood by me during the time I was incarcerated. The consequences have been primarily emotional on me. I do not have the same confidence I had prior to all of this happening, and I often find myself shying away from group events and keeping more to myself and to my family. Perhaps that is not all bad.

I will never again do anything that is remotely close to anything that could be construed to be illegal or fraudulent. Since my conviction I have gone overboard in complying with any and all laws related to fraud or financial abuse. This is true even to the point of not taking advantage of things I have been advised to do by attorneys or accountants.

Students should realize that the government has a huge reach and has inexhaustible resources, and I will never put myself, my family, or my business in any situation that the government could construe to be in anyway illegal. Don't take any chances in things that cut corners, don't go into murky areas, don't go along with others whose confidence you may think you have, and don't try to take advantage of the system. Do what is right, stick with that, and get advice from legal counsel if you are unsure of whether something may be considered a violation. Stay out of the radar of the government. Keep your own counsel. Treat others with respect, dignity, and honesty. Don't stray from those notions even one iota. Find your spiritual dimension and incorporate that in every step of your life.

I've served my time and was released from prison. I'm officially retired but still involved in our business on an advisory basis. I spend as much time with my wife, children, and grandchildren as I am able. They were so loyal to me when I needed that comfort of loyalty, and I will never trade that for any accolades the "world" might offer. 


\section{WILMAR}

As a successful business owner and CEO in Germany, life was good, and I was sure everything was going to keep going the way it had in the past. Now as a 62- year-old man serving his last year in prison, I have a different perspective.

I was found guilty of tax evasion, and my life has never been the same since. It took about ten years from the time I was caught until I was actually convicted. This was because the authorities were looking for more evidence of my crime and to see if any other crimes had been committed.

When I am released I will live a more conscious life and always think before I act. I will pay attention to how others can impact my life, legally speaking. The tax evasion I was found guilty of is due to a third party (the shipper) claiming something that was not true. The valuation of the transaction, as reported by the shipper, was much greater than reported on the shipping documents, and when it was discovered, I was arrested for not paying the proper tax on the goods. In the future I will not put as much trust in other parties with whom I do business, will make sure I know the proper values, and, of course, pay the proper taxes.

When I am released from prison in the next year I hope to find a way to continue the independence of selfemployment I enjoy so much. I would like to be a merchant.

\section{ROBERT}

As a successful U.S. bank vice-president and loan officer, I never dreamed that someday I would be spending 51 months of the prime of my life in a federal prison. But thanks to my FBI indictment and court conviction on bank fraud and wire fraud, here I am.

Mine is a complicated story. I made several legal transactions that resulted in an illegal transaction. Please allow me to explain. It was not illegal for my bank to lend my father-in-law money to purchase a house. When he got the bank loan, my father-in-law then sold the house he currently owned. My father-in-law would not have sold his house if he did not get the loan from the bank to buy a new house. The issue arose when the proceeds of the home my father-in-law sold went to my family. I, therefore, received money due to the loan from my bank, which is illegal. I assumed it was fine. I never received any money through intentional fraud or deceit. My crime was merely in initiating the transaction.

Time in prison has allowed me to reflect upon many things. The first and foremost lesson most of us in prison seem to understand too late is that no success can compensate for failure in the home. No corporation or job will ever provide the satisfaction and joy that comes from your child. No dollar amount of income will comfort a lonely bride's heart, like a kind word or understanding ear can comfort her. No house, despite its size, will help a child prepare for life's trials like the experienced guidance of a loving, attentive father. Your family comes first above all else. Spend time with your family! I have four small children, who now don't get to see their daddy much at all, except for an occasional prison visit.

The second lesson all of us in prison seem to come to understand is that there seems to be little justice in the justice system. Innocent until proven guilty, in the federal justice system, seems like a myth to many who have been indicted. Most of us are left trying to prove something did not happen. And proving a negative is very difficult. When accused of stealing money it is the accused's responsibility to prove they did not steal. This is a shock to most of us who believe the system was established to protect the innocent and that the "truth will set you free."

The third lesson most prisoners seem to arrive at is one that comes only through introspection and self-examination. Decisions should be based on principles and not on the situation at hand. 


\section{THEO}

I was a very successful professional with my own German firm and eight employees. At age 60, I never thought I would serve time in jail or commit a felony. I had never committed any crime in my lifetime.

It started when I became unable to work due to an injury. It wasn't my fault; the injury happened when I was assaulted during a robbery. Due to some technicalities, my health insurance wouldn't cover my resulting medical bills. As a successful professional for over three decades, I was arrogant and thought I could handle the situation myself. I wasn't used to asking others for help.

As a result of my long hospitalization from the injury, my law firm incurred severe financial distress. While going through bankruptcy, it was learned that income from clients had gone missing. The result was a large financial disaster for my clients. The courts sentenced me to four years for betrayal of trust, as well as fraud.

Due to my poor medical condition, I spent the first eight months in a prison hospital. This time and the time in prison since then have given me much opportunity to reflect. Before prison, I was much more concerned about my health and about me, personally. In prison, I've thought in detail about my actions and the consequences they had on others.

While in prison, I've contacted the victims of my crime and apologized. I've done everything possible to reverse the damage that was done.

Much of my family has been supportive of me while in prison. From what I know about other inmates here, that is not the norm! And although they are supportive, my family suffered from the crime having had to live with the shame, like I have. We are all hoping for a better future.

Even though my wife of 33 years did divorce me, I still have a good relationship with my ex-wife. I have lost almost all of my friends, even though I have reached out and contacted some of them.

I've learned that I need to seek help when help is needed, rather than try to do everything myself. Again, I blame my lack of doing so on personal pride. I thought I was smart enough to get through this all by myself. That was a mistake. Everything would have been avoidable had I contacted others when my problems started. It is better to work with others and seek advice in a timely manner without seeing this as a weakness.

Due to my age and health conditions I will probably only be able to do volunteer work when I am released. I will share my experience with others, hoping they avoid making the same mistakes that I made.

\section{DICK}

I've always believed in hard work and doing the right thing. Imagine my shame when I was sentenced to 72 months in prison for U.S. tax evasion. I owed the federal government $\$ 300,000$ in unpaid payroll taxes.

I was the owner of a successful and moderately large regional company that installed entertainment systems in people's homes. A very large retailer actually sold the equipment and then paid my company to install and service it. To work with such a reputable and large retailer sounded like a good business proposition, and that's why I signed the contract with them. And it all worked out great. At first.

Then the retailer got behind in payments for my installations. To this day, I don't know why they stalled in making their payments to my company. Regardless, I still had to make payroll and all of my expenses for installations. I kept thinking that things would turn around. As time went on, the retailer would make some payments for installations, then fall behind again in payments. I should note that the retailer was a very successful company, making millions of dollars of profits each year, so it's not like they were hurting for money. It's just that for some reason, they chose not to pay me. They made many excuses, but the result was the same: they didn't issue payments to me. 
I was in sort of a bind. I had a large installation staff and had to keep them busy, so I kept installing the systems, even though the payments from the retailer weren't coming in. All this time, I had to pay my bills and my workers, which I did. I paid all of my bills, except the bill to the federal government for payroll taxes. My accountant gave me bad advice, but it is still my fault for not informing the federal government. I kept getting reassured from the retailer that the money was coming, and I promised myself I would pay off the payroll taxes at that time. But the money never did come. Not even to this day.

I was indicted on 27 counts of tax evasion, once for every period that I failed to pay taxes. I plead guilty to three of them, resulting in my sentence.

My advice is this: realize that you are going to face ethical dilemmas in your working world. Face them head on and do the right thing. Do not live with the thought that you can start doing the right thing in the future, as soon as things get better. Do the right thing today and everyday. Trust me; you do not want to go to prison! And after I get out, I still have to pay off that $\$ 300,000$ in back taxes, plus $\$ 700,000$ in penalties, even though I no longer have a company.

\section{ROLPH}

I was a 41- year-old company officer in Germany with great authority, and life seemed good. I was sentenced to 2 years and 9 months for the granting of an undue advantage and fraud. The crime, my first, was committed out of a dilemma. The bottom line is that I engaged in business with friends, made the mistake of not putting it in writing, and didn't verify that what my friends were supposed to do had actually occurred. I never believed I would go to prison!

My time in prison has been a very negative experience for me. The impact has been nothing but negative for my wife as well. She still has a household to run and children to care for, but she gets no financial support from me. My two children are very embarrassed by my crime and my time in prison, and my friends are also embarrassed for me. The only positive outcomes are that prison time has helped me get a bit closer to some of my friends, plus I have gone sober, lost weight, and read some books I've wanted to read.

My advice is this: make no decisions if you are cornered. Take time to discuss decisions with your co-workers. Make sure all of your contracts are legally sound and that you have proper witnesses when closing contracts. Always consider the legal consequences and inform yourself completely. Never assume someone else is going to inform you that an action might be illegal or questionable.

For my future, I hope to be in company management in some capacity. If so, I can assure you, I will make sure all business interactions are clear and unambiguous.

\section{LARRY}

I'm in my mid-60s and serving 63 months in a federal prison. When I get out, I will have to find some way to pay $\$ 400,000$ in restitution. How did I get here?

I am someone who is driven to get results. I've been classified as a Type A personality, someone who is driven to achieve results and accomplish goals. For example, I was the president and CEO of four U.S. companies, managing partner of one LLC, and on the Board of Directors of two other companies.

As a board member of one organization, I tried to help bring business sense to the meetings since most members didn't seem to understand accounting, balance sheets, and so forth. The organization had a hospital that needed renovating. Plans were coming along well, but we were having trouble putting together the final pieces of financing. So, several board members decided to borrow the money needed for the renovation and then sell it back to the hospital. It was in those transactions that my illegal activities occurred. 
My 86- year-old father is the one that first told me I was indicted. He found out by reading the newspaper-it was front-page news! Imagine my shock and shame! Interestingly, the others who were partners in putting together the financial arrangement were not indicted. The federal authorities get to decide who they want to indict. They can indict some, all, or just one person. I was found guilty of conflict of interest and conspiracy to commit Medicare/Medicaid fraud. My wife was sentenced also, and she went to a women's federal prison for 33 months.

My counsel is to carefully choose what you decide to undertake. While it may sound mean, don't try to do everything you can for everybody. And always obey the laws. If you don't know the laws or understand the details of the laws, then find someone who does!

Find out what your life's mission is and maintain focus on that mission. Write it down as a personal mission statement, so that when you accept positions of responsibility you can also keep that focus in challenging situations. That's especially important for those of us who tend to be leaders and doers, especially for those with little patience when things are not being accomplished as quickly as one would like.

\section{ACKNOWLEDGEMENTS}

Special thanks to the prison authorities in Germany and to the assistance of Dr. Stefan Suhling, Matthias Ritter, Anna Kanalieva-Vacheva, Dr. Klaus Beckmann, Gina Chiodi Grensing, and the Leibniz FH School of Business.

\section{AUTHOR BIOGRAPHY}

Stephen B. Castleberry has been Professor of Marketing and Business Ethics at UMD since 1992 where he teaches marketing and business ethics courses. Steve has received the Beta Gamma Sigma Professor of the Year Award, UMD Outstanding Faculty Advisor Award, Horace T. Morse-Minnesota Alumni Association Award for Outstanding Contributions to Undergraduate Education, Hormel Meritorious Teaching Award, and others. Dr. Castleberry has published over 45 referred journal articles in national and international publications, is the co-author of nine editions of Selling: Building Partnerships by McGraw Hill, and serves on a number of editorial boards.

\section{ADDITIONAL RESOURCES FOR STUDENTS}

Bell, J. J., \& Gaerte, K. M. (2015). New playbook for prosecuting white collar crime. Indiana Lawyer, 26(16), 21-25. Describes new guidelines for federal prosecutors of white collar crime.

Blickle, G., Schlegel, A., Fassbender, P., \& Klein, U. (2006). Some personality correlates of business white-collar crime. Applied Psychology: An International Review, 55(2), 220-233. An extension of previous investigation of U.S. white collar criminals that examines German white collar criminals.

Craft, J. (2013). Living in the gray: Lessons on ethics from prison. Journal of Business Ethics, 115(2), 327-339. Narratives of white collar prisoner stories captured by students in a college class.

Federal Bureau of Investigation (2015). White-collar crime. Retrieved from: http://www.fbi.gov/aboutus/investigate/white_collar/whitecollarcrime. Describes and provides examples of white collar crime, as well as fraud prevention mechanisms.

Hauser, R., Asaad, C. T., \& Bartholow, J. (2015). You decide: The company you keep. Journal of Financial Education, 41(2), 157-181. Statistics about income/education levels of white collar prisoners, with insights for new finance employees.

Kirby, J. (2015). Bully for the white-collar crackdown. Maclean's, 128(38), 47. Highlights trends that white collar crime enforcement will impose punishment on individuals and not just firms.

U.S. Sentencing Commission (2015). Guidelines Manual. Retrieved from: http://www.ussc.gov/guidelines-manual/2015/2015ussc-guidelines-manual.These guidelines help determine the sentence and fines that most U.S. white collar prisoners are dealt. 


\section{CASE QUESTIONS/FOLLOW-UP}

1. What do you think you have in common with these people that might tempt you to do the same things they did?

2. Can you identify anything that you are actually doing right now that might be putting you on a path to illegal behavior? If you would rather not answer this about your own life, answer the question based on the life of one of your friends (i.e., is your friend doing anything right now that might be putting him/her on a path to illegal behavior?).

3. What mechanisms can you put into place in your life that will help you avoid breaking laws?

4. List three main takeaways you feel are important from these stories. 